\title{
ETIOLOGICAL ASPECTS OF GASTRO-ENTERITIS*
}

BY

\author{
E. HINDEN, M.D., M.R.C.P.
}

The group of diseases known officially as ' diarrhoea and enteritis under two years of age' is one of the major hazards which menace the hife of the young infant. The group consists of several seemingly distinct clinical entities; one of these, known from its incidence as 'epidemic diarrhoea of the newborn' has recently attracted much attention-to a degree out of proportion to its importance as a killing disease. For indeed the as yet undifferentiated remainder, less severe but more widespread, cause a much greater loss of life. The etiology of these diseases, and their relationship within the group, are not yet fully determined; the object of this study is to help elucidate these two problems.

Gastro-enteritis, to use a non-specific name for all the intestinal disorders, was particularly severe in the district of North Kensington, a part of the Royal Borough of Kensington, during the years 1938-39-40 (table 1). Kensington had the highest

TABe 1

TOTAL INFANT MORTALITY UNDER ONE YEAR AND GASTRO-ENTERTIS MORTALITY UNDER TWO YEARS FAR ENGLAND AND WALES, AND THE BOROUGH OF KENSINGTON : RATES PER 1,000 LIVE BIRTHS (REGISTRAR-GENERAL, 1938d)

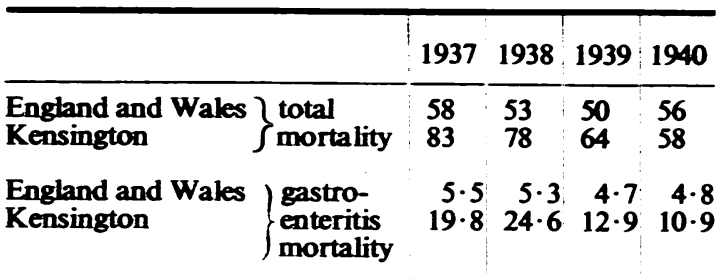

gastro-enteritis mortality rate in 1938 of all the Metropolitan Boroughs, and was second in 1937 and 1939. Correspondingly, the total infant mortality rate was also high, the borough being worst on the list in 1937 and 1939. The figures show that this was due mainly, but not entirely, to the high death rate from enteritis.

The relative importance of gastro-enteritis as a killing disease of infancy has increased of late. The death rate for the ordinary infectious diseases \footnotetext{
- Based on a thesis for the M.D. degree of the University of
Cambridge.
}

of infancy, and for tuberculosis, have both fallen steadily during the past ten years to about half their former value; but the death rate for " enteritis and diarrhoea" has fallen only a little. Gale (1945) in his discussion of the secular trends of disease in childhood, points out that until 1921 the fatality from this disease was decreasing rapidly, but that since that date it has remained stationary, even though total infant mortality has continued to fall (table 2). A similar phenomenon has been noticed in America, where Frant and Abramson (1944) stress that while deaths due to diarrhoea in the age groups one to twelve months have fallen in the years 1926-1939, those in the first month of life have actually risen. The English figures show that gastro-enteritis alone is responsible for about 10 per cent. of the total infant mortality. But, of this total, nearly half is due to causes which operate before the baby is well and truly launched into the world. Such are prematurity and congenital deformities, and the mortality due to them is given in line 4 of table 2 . The mortality due to birth injury, approximately $2 \cdot 5$ per thousand, should also be added to this. What is left is the mortality sustained by healthy, normally-born babies, and of this, gastro-enteritis is responsible for about 16 per cent. It is surpassed in importance as a killing disease only by pneumonia. During the three bad years in Kensington, although no outbreak of diarrhoea neonatorum was encountered, enteritis was responsible for eighty-one out of the 120 deaths under one year that took place in the County Hospital; pneumonia caused twenty-three, and all other conditions but sixteen.

\section{Clinical Material}

The clinical material to be considered consists of all cases of gastro-enteritis treated in the County Hospital during the twenty-four months from April 1, 1938, to March 31, 1940. There were 148 such, of whom sixty-five died and eighty-three recovered-a case-mortality of 44 per cent. An additional twenty fatal cases are included in the discussion of aspects of etiology other than casemortality; ten were admitted between January and March, 1938; and another seven, admitted during 1937, also died within these three months; three more died in the period April to December, 1940. 
TABLE 2

INFANT MORTALITY (DEATHS UNDER ONE YEAR PER 1,000 LIVE BIRTHS) FROM CERTAIN CAUSES: 1931-40 (REGISTRAR-GENERẠL 1940)

\begin{tabular}{|c|c|c|c|c|c|c|c|c|c|c|}
\hline & 1931 & 1932 & 1933 & 1934 & 1935 & 1936 & 1937 & 1938 & 1939 & 1940 \\
\hline 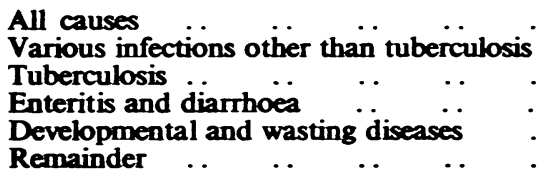 & $\begin{array}{l}66 \\
5 \cdot 0 \\
1 \cdot 04 \\
5 \cdot 4 \\
28 \cdot 3 \\
26 \cdot 6\end{array}$ & \begin{tabular}{l|}
65 \\
$5 \cdot 2$ \\
$1 \cdot 00$ \\
$6 \cdot 2$ \\
$28 \cdot 3$ \\
$24 \cdot 4$
\end{tabular} & \begin{tabular}{l|}
64 \\
$4 \cdot 5$ \\
$0 \cdot 82$ \\
$6 \cdot 4$ \\
$29 \cdot 1$ \\
$23 \cdot 0$
\end{tabular} & $\begin{array}{l}59 \\
4 \cdot 0 \\
0 \cdot 68 \\
5 \cdot 0 \\
27 \cdot 6 \\
21 \cdot 3\end{array}$ & $\begin{array}{l}57 \\
3 \cdot 1 \\
0 \cdot 55 \\
5 \cdot 3 \\
27 \cdot 1 \\
20 \cdot 9\end{array}$ & $\begin{array}{l}59 \\
3 \cdot 9 \\
0 \cdot 59 \\
5 \cdot 6 \\
26 \cdot 8 \\
21 \cdot 7\end{array}$ & $\begin{array}{c}58 \\
3 \cdot 2 \\
0 \cdot 63 \\
5 \cdot 3 \\
26 \cdot 9 \\
21 \cdot 6\end{array}$ & $\begin{array}{c}53 \\
2 \cdot 4 \\
0 \cdot 60 \\
5 \cdot 1 \\
24 \cdot 9 \\
19 \cdot 7\end{array}$ & $\begin{array}{c}50 \\
2 \cdot 3 \\
0 \cdot 51 \\
4 \cdot 3 \\
24 \cdot 7 \\
18 \cdot 6\end{array}$ & $\begin{array}{l}56 \\
2 \cdot 8 \\
0 \cdot 59 \\
4 \cdot 4 \\
25 \cdot 0 \\
23 \cdot 1\end{array}$ \\
\hline
\end{tabular}

This makes a total of eighty-five fatalities, which is the number of deaths from gastro-enteritis during the three years 1938-39-40.

\section{Case Mortality and Seasonal Incidence}

This disease notoriously carries a heavy casemortality; taking together the figures given in six recent studies in this country, the average casemortality is one in three (table 3 ).

Taru 3

CASE-MORTALITY OF GASTRO-ENTERTIS

\begin{tabular}{|c|c|c|c|c|}
\hline Author & & $\begin{array}{l}\text { Total } \\
\text { cases }\end{array}$ & Deaths & $\begin{array}{l}\text { Case-morthlity } \\
\text { per cent. }\end{array}$ \\
\hline 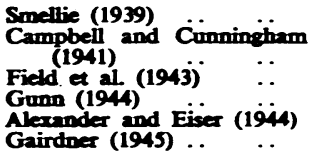 & $\begin{array}{l}\cdots \\
\cdots \\
\cdots \\
\cdots \\
\cdots\end{array}$ & $\begin{array}{l}500 \\
574 \\
100 \\
411 \\
140 \\
216\end{array}$ & $\begin{array}{r}240 \\
159 \\
23 \\
88 \\
8 \\
109\end{array}$ & $\begin{array}{l}48 \\
27 \cdot 7 \\
23 \\
21 \cdot 4 \\
50 \\
50\end{array}$ \\
\hline Total & $\cdots$ & 1,941 & 627 & $32 \cdot 3$ \\
\hline This series & $\cdots$ & 148 & 65 & 44 \\
\hline
\end{tabular}

The distribution by age and sex of patients dying of the disease in England and Wales, and of the present series, is given in table 4 . It will be seen (country-wide figures) that the incidence is fairly uniform over the first six months, being highest at about three months; it falls sharply after the end of the first year. This agrees well with the present series, and with the figures given by individual authors. Thus Gunn (1944) found that the agegroup three to six months contained the largest number of cases (125 out of 411), and suffered also the highest case mortality, 30.4 per cent. The case mortality of the present series is: below three months, 60 per cent.; three to six months, 55 per cent.; six to nine months, 32 per cent.; nine to twelve months, 44 per cent.; one to two years, 15 per cent. The mean age of the fatal cases was 4.9 months; 70 per cent. of deaths occurred before six months of age, and only 5 per cent. after one year.

At all ages, baby boys suffer more than baby girls (4,321 boys and 3,677 girls), and the excess of male deaths is far more than would be expected on random sampling.

The seasonal incidence both for the country as a whole and in this series, is shown in table 5. Looking at the country-wide figures for the individual years, it is seen that December is one of the worst three months in every year, and January is so twice; these two months have the worst averages also. More detailed analysis $\left(X^{2}\right.$ test) shows that the high figures given by these months are unlikely to have arisen by random sampling, while the variations between the other months are of no significance.

This high winter incidence is all the more striking when it is recalled that formerly this disease was called 'summer diarrhoea.' Writing on this point, Gale (1945) says: "The cause of this summer diarrhoea of infants is unknown, but from its epidemiological history it looks almost as though a disease had disappeared in the last war, except for a dying spurt of activity in 1921, and that the infantile diarrhoea of the present day, with its steady death rate and its higher incidence in winter may have a different causation.'

Other investigators also have noticed that the former high summer incidence is not found nowadays. Gairdner (1945) and Smellie (1939) both found that there was no particular seasonal incidence in their series, the latter explicitly remarking that 'summer diarrhoea is over.' On the other hand, Campbell and Cunningham (1941) found more cases in summer and autumn than in winter.

Consideration of the figures of the present series of cases shows that the incidence of the disease was highly irregular. There were three waves of high incidence: May, June, and July, 1938; November and December, 1938 and January, 1939; and February, 1940. The overall monthly average for the period was 6.2 cases; for the seven worst months it was nearly 12 , and for the remaining seventeen months it was $3 \cdot 8$. 'Summer diarrhoea' was conspicuously absent.

\section{The Outbreak of War}

It is interesting to examine the number of deaths in the borough in the months after the outbreak of war. The early winter rise in deaths did not occur; February suffered a heavy epidemic, and thereafter 
TABUE 4

DEATHS DUE TO GASTRO-ENTERITIS, BY AGE AND SEX: ENGLAND AND WALES (REGISTRAR GENERAL 1938a), AND THIS. SERIES

\begin{tabular}{|c|c|c|c|c|c|c|c|}
\hline & & $\begin{array}{l}\text { Under } \\
4 \text { weeks }\end{array}$ & $\begin{array}{l}4 \text { weeks } \\
3 \text { months }\end{array}$ & $\begin{array}{c}3-6 \\
\text { months }\end{array}$ & $\begin{array}{c}\text { 6-12 } \\
\text { months }\end{array}$ & $\begin{array}{r}1-2 \\
\text { years }\end{array}$ & Totals \\
\hline $1938:$ males & \begin{tabular}{ll|} 
& \\
$\cdots$ &.
\end{tabular} & $\begin{array}{r}153 \\
94\end{array}$ & $\begin{array}{l}535 \\
284\end{array}$ & $\begin{array}{l}638 \\
425\end{array}$ & $\begin{array}{l}511 \\
380\end{array}$ & $\begin{array}{l}156 \\
119\end{array}$ & $\begin{array}{l}1,993 \\
1,302\end{array}$ \\
\hline 1939 : males & $\begin{array}{l}. \\
\ldots\end{array}$ & $\begin{array}{l}138 \\
101\end{array}$ & $\begin{array}{l}433 \\
274\end{array}$ & $\begin{array}{l}523 \\
376\end{array}$ & $\begin{array}{l}423 \\
311\end{array}$ & $\begin{array}{l}117 \\
116\end{array}$ & $\begin{array}{l}1,634 \\
1,178\end{array}$ \\
\hline 1940 : males & $\begin{array}{l}. . \\
\cdots\end{array}$ & $\begin{array}{l}201 \\
142\end{array}$ & $\begin{array}{l}503 \\
342\end{array}$ & $\begin{array}{l}488 \\
341\end{array}$ & $\begin{array}{l}367 \\
271\end{array}$ & $\begin{array}{l}135 \\
101\end{array}$ & $\begin{array}{l}1,694 \\
1,197\end{array}$ \\
\hline $\begin{array}{c}\text { Total : males } \\
\text { females }\end{array}$ & $\begin{array}{l}. . \\
\cdots\end{array}$ & $\begin{array}{l}492 \\
337\end{array}$ & $\begin{array}{r}1,471 \\
900\end{array}$ & $\begin{array}{l}1,649 \\
1,142\end{array}$ & $\begin{array}{r}1,301 \\
962\end{array}$ & $\begin{array}{l}408 \\
336\end{array}$ & $\begin{array}{l}5,321 \\
3,677\end{array}$ \\
\hline $\begin{array}{l}\text { This series : males } \\
\text { females }\end{array}$ & s $\}$ & 2 & 20 & 38 & 21 & 4 & $\left\{\begin{array}{l}56 \\
29\end{array}\right.$ \\
\hline
\end{tabular}

the disease almost disappeared. This may be compared with the movement of the population: expectant mothers, and infants, were evacuated after the declaration of war, but as London did not sustain the expected bombing they trickled back as the winter passed. Yet the population fluctuations were nothing like as great as would be required to explain the fall in incidence on a simple per capita basis. The summer months were quiet; heavy bombing started in the autumn of 1940 , causing the second wave of emigrations from London; and with this the winter of $1940-41$ was very free from this disease.

\section{Inffuence of Breast Feeding}

The influence of breast feeding on gastro-enteritis has been noticed by several writers; it lessens both incidence and case mortality. Thus Robinson (1940) found that diarrhoea occurred in eighty of 171 artificially fed babies, but in only six of thirty-seven infants on the breast; the discrepancy is significant $(P<0 \cdot 01)$. Ebbs and Mulligan (1942) considering 314 cases of gastro-enteritis, found that only seven (2. 2 per cent.) were wholly breast-fed, and seventynine ( 25.2 per cent.) partly breast-fed; while in the general population 35.6 per cent. were wholly breast-fed, and $36 \cdot 2$ per cent. partly so. This is a considerable lowering of the incidences, and the differences are significant. Smellie (1939), Campbell and Cunningham (1941), Alexander and Eiser (1944), Gairdner (1945), and Weihl et al. (1947) also report a low incidence of this disease in breast-fed babies, but their figures do not include the proportion of breast-fed babies in the general population. With regard to mortality, Gunn (1944) found that the disease was not only less frequent, but also milder in the breast-fed, and Ormiston (1941) agrees that fewer breast-fed babies die of this disease. Ebbs and Mulligan (1943) curiously enough find a higher mortality among the breast-fed, possibly because the milder cases among the breast-fed babies were not admitted to hospital. The other writers mentioned above find the case mortality of the breast-fed about half that of the bottle-fed babies. Two further experiences may be quoted. Sakula (1943), describing an epidemic in a maternity nursery, found that, of eighteen infants who contracted the disease, fifteen died, all of them artificially reared. Cron et al. (1940), dealing with a similar attack in America, found eighteen deaths in twenty-two cases; here again, only the bottle-fed babies died; all the breast-fed babies recovered. Most writers agree that even a few weeks' breastfeeding improves the prognosis, even though the baby may be long off the breast when he falls ill.

There are, however, two recorded opinions differing from this view. Rice et al. (1937), writing of 'epidemic diarrhoea of the newborn,' state that breast-fed babies were as prone to infection as the others; and Lyon and Folsom (1941), describing a particular outbreak, found that the majority of the babies were breast-fed.

In the series under review, the information about breast-feeding is unfortunately far from complete. Of the eighty-five who died, thirteen were breast-fed up to their death, and another thirteen had been breast-fed for at least six weeks; the others had not been breast-fed for more than a short time. It appears that over 30 per cent. of the infants who succumbed had been breast-fed for six weeks or more - a period commonly considered to give a good resistance to this disease. Breast feeding did not afford the expected high protection against the virulent form of gastro-enteritis prevailing in the neighbourhood during those years. The data on the incidence of breast feeding among the recovered infants are too scanty to be of value. 
Taber 5

MONTHLY INCIDENCE OF GASTRO-ENTERITIS IN 1938-39-40 (REGISTRAR-GENERAL 1938b)*

\begin{tabular}{c|ccc|c|c|c|c|c|c|c|ccc}
\hline & Jan. & Feb. & Mar. & Apr. & May & June & July & Aug. & Sept. & Oct. & Nov. & Dec. \\
\hline 1938 & 498 & 429 & 374 & 319 & 344 & 335 & 450 & 481 & 422 & $459 \dagger$ & $441 \dagger$ & $490 \dagger$ \\
1939 & 348 & 274 & 308 & 315 & 257 & 311 & 293 & 279 & 226 & 264 & 277 & 414 \\
1940 & 380 & 347 & 339 & 289 & 330 & 367 & 354 & 394 & 417 & 404 & 375 & 416 \\
\hline Average & 409 & 350 & 340 & 308 & 310 & 338 & 366 & 385 & 355 & 376 & 331 & 440
\end{tabular}

Monthly incidence of 148 cases of gastro-enteritis (this series)

\begin{tabular}{|c|c|c|c|c|c|c|c|c|c|c|c|c|}
\hline $\begin{array}{l}1938 \\
1939 \\
1940\end{array}$ & $\begin{array}{r}11 \\
7\end{array}$ & $\begin{array}{r}5 \\
12\end{array}$ & $\begin{array}{l}2 \\
5\end{array}$ & $\begin{array}{l}4 \\
6\end{array}$ & $\begin{array}{r}11 \\
4\end{array}$ & $\begin{array}{l}8 \\
6\end{array}$ & $\begin{array}{r}12 \\
2\end{array}$ & 1 & $\begin{array}{l}3 \\
4\end{array}$ & $\begin{array}{l}4 \\
7\end{array}$ & $\begin{array}{r}10 \\
2\end{array}$ & $\begin{array}{r}19 \\
3\end{array}$ \\
\hline Average & 9 & $8 \cdot 5$ & $3 \cdot 5$ & 5 & $7 \cdot 5$ & 7 & 7 & 0.5 & $3 \cdot 5$ & $5 \cdot 5$ & 6 & 11 \\
\hline
\end{tabular}

"Note: This disease is NOT "diarrhoea and enteritis under two years", but "diarhoea and enteritis other than colitis, not due to intestinal ulceration." The great majority of this group, bowever, is diarrhea and enteritis under two years.)

+ Figures are for 1937 .

Urban and Rural Areas

Gastro-enteritis is predominantly a disease of the urban community; it falls much less heavily on the inhabitants of the countryside (table 6). It will

TABUE 6

DEATHS FROM GASTRO-ENTERITIS UNDER ONE YEAR AS A RATE PER I000 LIVE BIRTHS IN VARIOUS PARTS AS T RA CO PER 1,000 LIVE BIRTHS, IN VARIOUS PARTS

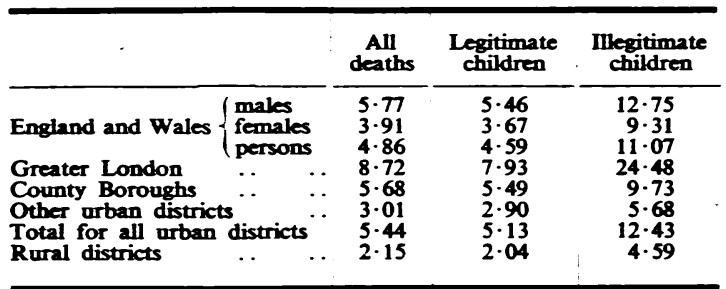

Publication of this table was suspended for the years 1939 and 1940.

be seen that the death rate falls with the density of the population; Gairdner (1944) also draws attention to this fact. The same trend for neonatal mortality has recently been reported from Scotland (Department of Health for Scotland, 1947). Another curious fact shown by the table is the high death rate among illegitimate children in all areas, and particularly in Greater London.

\section{Hospital Infection}

There remains one other important etiological factor, hospital infection. Paterson (1944) says, - Debilitated infants contracting the disease in hospital show a much higher mortality than healthy infants contracting it at home '; and other writers also stress the dangers of hospital infection. Field et al. (1943) found fifteen deaths among forty-six hospital-contracted infections, as against eight among fifty-four home contracted ones-a significant difference, though Campbell and Cunningham (1941) failed to find any difference. Gairdner (1945) makes the important observation that gastroenteritis occurring in a ' recently discharged ' infant should really be considered as hospital-contracted. Hospital gastro-enteritis is extremely infectious (Ormiston, 1941; Gunn, 1944), and it is likely that some at least of the notorious relapses of this disease are due to reinfection. Alexander and Eiser (1944) state that, among seventy-three cases nursed in individual cells, there were six relapses and one death; while among sixty-seven nursed in a big ward, under the rigorous bed-isolation regime of a fever hospital, there were twenty-one relapses and five deaths, a highly significant finding.

Of the present series of 148 cases, eighty-eight infants were admitted with gastro-enteritis, and twenty-seven of these died, a case mortality of 31 per cent. There were sixty infants who contracted the disease in hospital, and of them thirtyeight died (63 per cent.). This is a very large difference. But in addition, there were nine infants (of whom four died) who contracted the disease within four days of leaving hospital, and who probably were infected there, and another eight infants (of whom four died) whose clinical history strongly suggests that they had recovered from the enteral infection with which they were admitted, only to contract another infection while in hospital. Making these adjustments, there were seventy-seven infants acquiring gastro-enteritis in hospital, of whom forty-six died (a case mortality of 60 per cent.; and seventy-nine. who contracted the disease at home, of whom nineteen died (24 per cent.). 
Hospital infection is more than twice as deadly as home infection; it was responsible for 49 per cent. of the cases, and for over 70 per cent. of the deaths. The diagram shows the distribution of these cases by months, according to whether the infection was contracted in hospital (above the line) or outside (below the line); the deaths are shown hatched. It shows the pronounced epidemic character of the hospital outbreaks as compared with the much steadier incidence of the outside cases.

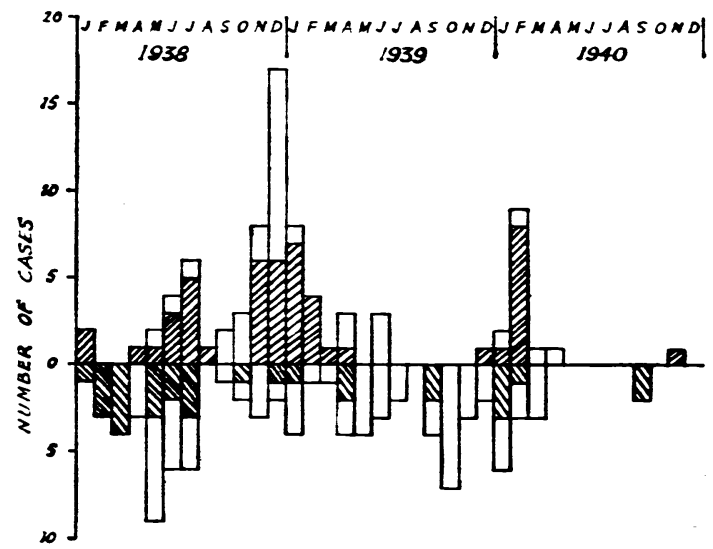

Fig.-Monthly distribution of cases of gastro-enteritis; infection contracted in hospital shown above the line, outside cases below the line. Fatal cases are shown hatched.

\section{Discuscion}

Three salient factors emerge from this study. The first is the seasonal incidence. The old 'summer diarrhoea' was a food-conveyed disease, with flies an important vector: naturally such a disease would have its greatest incidence in the warm months. But with improvements in hygiene, the withdrawal of horsed traffic from the towns, a rising standard of living, and better management of infant feeding by the public, this disease has virtually disappeared. It is possible that presentday enteritis is a new disease; more likely it has been slaying its tens all the time, though overshadowed by 'summer diarrhoea' slaying its hundreds. Were it also food-carried, it should have disappeared with its prototype. But it has not; and it is associated not with high summer, but with the season of coughs and sneezes. The close association between present day gastro-enteritis and respiratory infections is commented on by all authors; in one paper (Frant and Abramson, 1939), it is actually called ' upper respiratory diarrhoea'. There is a suggestion here that the noxious agent gains access to the infant through the respiratory channels.

The second is the beneficial effects of breast feeding. This is easy to understand: breast-milk is not liable to the same contamination as artificiallyprepared food, and, having a weaker buffering power than cows' milk, does not destroy the protective barrier of the gastric acidity. But these explanations do not cover the puzzling fact that a few weeks' breast feeding give protection even subsequently, when the baby is bottle-fed and therefore presumably at risk. They also do not explain why, in the two outbreaks of neonatal diarrhoea mentioned above, breast feeding afforded no protection. It is tempting to assume the presence of protective substances in breast-milk; this would explain both these discrepancies, but direct attempts to demonstrate such substances have failed.

The third important factor brought out is the higher mortality in towns. General sanitation and water supplies are better in the towns, the fly nuisance is less, and medical facilities are easier to obtain; nevertheless the disease is more deadly in the towns than in the countryside. One possible explanation is that rural mothers are more likely to breast-feed their nurslings than are urban mothers; but it is unlikely that this could account for the very big difference between Greater London and the County Boroughs. Another explanation is that the danger from gastro-enteritis increases with the concentration of susceptibles at risk, that is, roughly with the density of the population. This is known to be of great importance in determining the spread of other infectious diseases, such as measles; and it is interesting to note that the expected waves of measles epidemics did not occur after the evacuation of children from the densely populated cities, just as the expected winter epidemic of gastro-enteritis did not occur in Kensington in 1939-40.

The greatest concentration of susceptibles, of course, is found in the children's wards of hospitals, and it is here that the greatest infectivity and mortality are found. Other factors have to be appraised when considering hospital infectivity. The first is the enfeebled condition of the inmates, who presumably are not in good health. This factor has weight: it is shown later that one particular class of hospital admission, the infant who has done badly from birth, and is admitted because he is not getting on, rarely recovers from gastro-enteritis. But its importance should not be overstressed: with the above exception, it was found that the primary disease which secured entry of the infant to hospital is without effect upon the outcome of the enteritis, and it is common knowledge that hospital infections light on healthy nurslings admitted because of maternal disease and upon surgical cases in good general health. Another consideration is that the disease may be spread by faulty feeding technique. This view is taken by Stern (1947), who blames the milk-film which is left on the inside of the feeding bottle. But it is unlikely that this can be the whole explanation. High infectivity was found even with the strict barrier technique of a fever hospital; and while outbreaks of 'non specific gastro-enteritis' are 
common, those of proven food-conveyed disease (Salmonella and Shigella infections) are much rarer. Only one such outbreak occurred during the three years in the present series (Hinden, 1940). It is possible, too, that the virulence of the noxious agent may be heightened by passage.

There are probably two main factors concerned in the high death rate among illegitimate babies: the low incidence of breast-feeding, and the high proportion of them nursed in institutions.

The striking divergences between the published case mortalities (table 3) demand further attention. How was it that in North-West London only eight infants died out of 140 , while in West Middlesex 109 were lost out of 216 ? Such differences are commonplace in any compilation of case mortalities. It is out of the question that these divergences should have arisen by mere chance: the material cannot be homogeneous, the cases are not comparable. It seems indisputable that 'gastro-enteritis' is not a single disease; there is a mild type, probably again heterogeneous, and a severe type, epidemic in character, which prevails in different places at different times. It is this second type which causes most of the deaths, and it is this disease, occurring in many small localized epidemics during the winter, which is responsible for the heavy winter mortality. The evidence indicates that this disease was rampant in Kensington in 1937-39, in West Middlesex in $1944-45$, and in Liverpool in 1945-46. It is by no means coincidence that Sakula's (1943) report of an outbreak with a case mortality of over 80 per cent. also came from Middlesex. The figures for Liverpool are instructive: from July, 1945, to June, 1946, this city had 17,294 births and 330 deaths from enteritis; during the same period, London had 52,597 births and 320 deaths (Registrar-General, 1945-46). Liverpool had less than one-third the births of London, but more deaths, giving a death rate three times as large (the death rate is actually $19 \cdot 1$ per thousand, the same as Kensington in 1937). Small epidemics of this serious disease catch the public eye from time to time, as recently at Leicester and Preston, and during last summer on the U.S. Army Transport Zebulon B. Vance, carrying war brides and babies to the U.S.A. On this voyage, nineteen infants contracted the disease, and nine died. (Bulletin of U.S. Army Medical Department, 1946.) It is this disease, epidemic in concentrations of susceptible infants in the winter months, associated with respiratory infection, which kills 3,000 infants each year. There is as yet no method of differentiating it from other forms of gastro-enteritis, though it may be connected with the distinction between 'dehydrated' and 'non-dehydrated' cases made by most observers. Nevertheless, it is possible that in the future this illness may be as clearly distinguished from other intestinal disorders, as is typhus fever from typhoid fever to-day.

\section{REFERENCES}

Alexander, M. B. and Eiser, Y. (1944). Brit. med. J., 2, 425.

Bulletin of the U.S. Army Medical Department (1946). August, p. 112.

Campbell R. M. and Cunningham, A. A. (1941). Arch. Dis. Childh., 16, 211.

Cron, R. S., Shutter, H. W. and Lahmann, A. H. (1940). Amer. J. Obstet. Gynec., 40, 88.

Department of Health for Scotland (1947). Neonatal Deaths due to Infection. Edinburgh. H.M.S.O., p. 10.

Ebbs, J. H. and Mulligan, F. (1942). Arch. Dis. Childh., $17,217$.

Field, C. E., MacCarthy, D. and Wyllie, W. G. (1943). Brit. med. J., 1, 371.

Frant, S. and Abramson, H. (1939). N. Y. State J. Med., 39i, 784.

(1944). In Brennemann's Practice of Pediatrics. W.F. Prior Company, vol. 1, chap. 28, Sect II.

Gairdner, P. (1944). Proc. roy. Soc. Med., 37, 480.

(1945). Arch. Dis. Childh., 20, 22.

Gale, A. H. (1945). Ibid., 20, 2.

Gunn, W. (1944). Brit. J. Dis. Child., 41, 1.

Hinden, E. (1940). Lancet, 1, 145.

Lyon, G. M. and Folsom, T. G. (1941). Amer. J. Dis. Child., 61, 427.

Ormiston, G. (1941). Lancet, 2, 588.

Paterson, D. (1944). In Sick Children, Diagnosis and Treatment. Cassell and Co. London, p. 102 et seq.

Registrar-General (1938a). Statistical Review of England and Wales for the year 1938. H.M.S.O. London. Tables Part I, Medical. Table 22, 171; 1939, 143; 1940, 148.

(1938b). Ibid. Table 23, 183; 1939, 155; 1940, 162.

(1938c). Ibid. Table 14, 54.

(1938d). Ibid. Table 10, 44; 1940, 45.

(1940). Ibid. Table 12, 52.

$(1945 / 46)$. Abstracted from the Weekly Returns of Births, Deaths and Infectious Diseases. H.M.S.O. London. Table 2.

Rice, J. L., Best, W. H., Frant, S. and Abramson, H. (1937). J. Amer. med. Ass. 109, 475.

Robinson, E. C. (1940). Amer. J. Dis. Child., 59, 1002.

Sakula, J. (1943). Lancet, 2, 758.

Smellie, J. M. (1939). Ibid., 1, 969 and 1026.

Stern, D. M. (1947). Ibid., 1, 80.

Weihl, C., Rapoport, S. and Dodd, K. (1947). J. Pediat., 30, 45. 